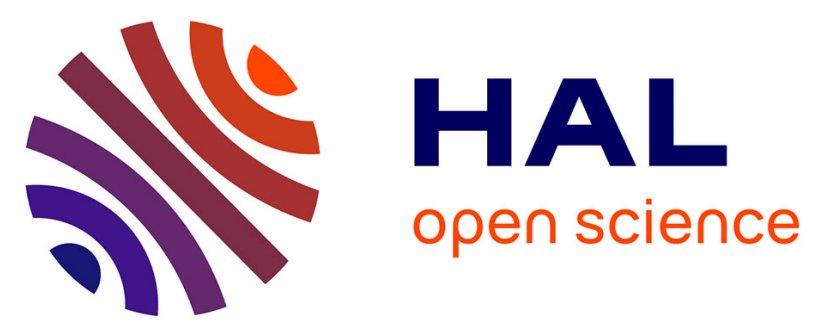

\title{
Micro- and macroscopic observations of the nucleation process and crystal growth of nanosized Cs-pollucite in an organotemplate-free hydrosol
}

Eng-Poh Ng, Aleid Ghadah Mohammad S, Séverinne Rigolet, T. Jean Daou, Svetlana Mintova, Tau Chuan Ling

\section{To cite this version:}

Eng-Poh Ng, Aleid Ghadah Mohammad S, Séverinne Rigolet, T. Jean Daou, Svetlana Mintova, et al. Micro- and macroscopic observations of the nucleation process and crystal growth of nanosized Cs-pollucite in an organotemplate-free hydrosol. New Journal of Chemistry, 2019, 43 (44), pp.1743317440. 10.1039/C9NJ03151K . hal-02410473

\section{HAL Id: hal-02410473 https://hal.science/hal-02410473}

Submitted on 26 Nov 2020

HAL is a multi-disciplinary open access archive for the deposit and dissemination of scientific research documents, whether they are published or not. The documents may come from teaching and research institutions in France or abroad, or from public or private research centers.
L'archive ouverte pluridisciplinaire HAL, est destinée au dépôt et à la diffusion de documents scientifiques de niveau recherche, publiés ou non, émanant des établissements d'enseignement et de recherche français ou étrangers, des laboratoires publics ou privés. 
Cite this:

\title{
Micro- and Macroscopic Observations of the Nucleation Process and Crystal Growth of Nanosized Cs-Pollucite in Organotemplate-free Hydrosol
}

\author{
Eng-Poh Ng, ${ }^{a, \dagger}$ Aleid Ghadah Mohammad S, ${ }^{a, b}$ Severinne Rigolet, ${ }^{c, d}$ T. Jean Daou, ${ }^{c, d}$ \\ Svetlana Mintova, ${ }^{\text {eff }}$ Tau Chuan Ling ${ }^{g}$
}

\begin{abstract}
The nucleation and crystal growth of nanoscale cesium pollucite aluminosilicate zeolite (ANA topology) from an organotemplate-free precursor suspension are reported. By using a new and reactive synthesis recipe $\left(5.5 \mathrm{SiO}_{2}: 1 \mathrm{Al}_{2} \mathrm{O}_{3}: 6 \mathrm{Cs}_{2} \mathrm{O}: 140 \mathrm{H}_{2} \mathrm{O}\right)$, zeolite nanocrystals with higher $\mathrm{Al}$ content $(\mathrm{Si} / \mathrm{Al}$ ratio $=2.12)$ are obtained within 120 min under mild condition $\left(180^{\circ} \mathrm{C}\right)$ which is much faster and safer as compared to those previously reported. The solid initially experiences amorphous phase re-organization before nucleation, crystallization and crystal growth take place. The resulting Cs-pollucite nanocrystals (average size $55 \mathrm{~nm}$ ) display trapezohedron morphology. The nanocrystals are colloidally stabilized in water and they are very active in base-catalyzed cyanoethylation of dipropylamine reaction, giving $89.6 \%$ conversion at $180^{\circ} \mathrm{C}$ within $50 \mathrm{~min}$. In addition, high solid yield of nanocrystals (ca. $70 \%$ ) is also achieved, thus offering a green pathway for synthesizing zeolite nanocrystals with high basicity in large scale.
\end{abstract}

\section{Introduction}

Zeolites are crystalline microporous minerals composed of aluminate and silicate tetrahedral units. These molecular sieves are generally used in adsorption, ion-exchange and catalysis owing to their high ion exchange capacity and porosity, and unique framework structure. ${ }^{1-5}$ In recent years, decreasing the scale of crystallite size of zeolites to nanometer regime $(<100 \mathrm{~nm})$ has attracted immense research interest because of their exceptional properties (e.g. high external surface area, fast diffusivity, high surface charge density, high colloidal stability, etc.) and greater potentiality that is directly related to their particle size. ${ }^{6-9}$ Up to now, more than 240 types of zeolite frameworks have been synthesized with only about 20 types of zeolites and related microporous materials can be obtained in nanocrystal forms (ABW, ${ }^{10} \mathrm{AEI},{ }^{11} \mathrm{AFI},{ }^{12} \mathrm{AFO},{ }^{13} \mathrm{ANA},{ }^{14}{ }^{*} \mathrm{BEA},{ }^{15} \mathrm{CHA},{ }^{16} \mathrm{EDI}{ }^{7}$ EMT, ${ }^{17} \mathrm{FAU},{ }^{18,19} \mathrm{GIS}^{, 20} \mathrm{LTA}^{21} \mathrm{LTJ}^{22} \mathrm{LTL}^{23} \mathrm{MEL},{ }^{24} \mathrm{MER},{ }^{25} \mathrm{MFI},{ }^{26,27}$ $M O R,{ }^{28} \operatorname{SOD}^{29}$ ).

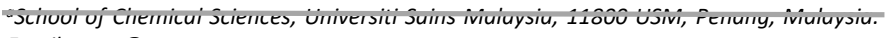
Email: epng@usm.my

${ }^{b}$ Department of Chemistry (Preparatory Year), Faculty of Science, University of Hail, P.O. Box 2440, Hail, Kingdom of Saudi Arabia.

'Université de Haute-Alsace, Axe Matériaux à Porosités Contrôlées, Institut de Science de Matériaux de Mulhouse UMR 7361, ENSCMu, 3b rue Alfred Werner, 68093 Mulhouse, France.

¿Université de Strasbourg, 67000 Strasbourg, France.

eLaboratoire Catalyse \& Spectrochimie, ENSICAEN, Université de Caen, 14000 Caen, France.

State Key Laboratory of Heavy Oil Processing, College of Chemical Engineering, China University of Petroleum (East China), Qingdao, 266580, China.

IInstitute of Biological Sciences, Faculty of Science, University of Malaya, 50603 Kuala Lumpur, Malaysia.
Cs-pollucite $\left(\mathrm{CsAlSi}_{2} \mathrm{O}_{6}\right)$ is a rare alkali metal zeolite. It has three-dimensional channel with 8-membered ring pore size (pore opening $2.43 \AA$ A) forming ANA framework structure. ${ }^{30}$ Cs-pollucite has recently been reported as a promising basic catalyst and host for storing radioactive cesium. ${ }^{31}$ In general, the synthesis of Cspollucite involves hydrothermal treatment at high temperature $\left(200-300^{\circ} \mathrm{C}\right)$ and pressure $\left(300-850\right.$ bar) where natural zeolite ${ }^{31}$ and soil ${ }^{32}$ are used as aluminosilicate sources. Its synthesis condition which uses high pressure and temperature, however, is considerably dangerous and proper reaction vessels with safety build in have to be employed.

The synthesis of nanosized zeolites requires a specific environment called supersaturation where such conditions allow control of the ultimate crystal size via nucleation process. In order to achieve this condition, harmful and costly organic templates in large excess amount are needed which makes the industrial scaleup process to be unfeasible and environment-unfriendly. ${ }^{21}$ Hence, fast crystallization of Cs-pollucite nanocrystals under very mild (low pressure and temperature) and eco-friendly (organotemplate-free) condition is still a great challenge in zeolite research.

In this paper, the induction, nucleation and crystal growth of Cs-pollucite zeolite nanocrystals in the organotemplate-free precursor suspension are reported. Unlike previous work, ${ }^{31,32}$ the formation evolution of zeolite is studied using a very reactive hydrosol under microscopy and spectroscopy where the crystallization time is significantly reduced from hours to minutes. 


\section{Experimental Section}

\section{Synthesis of Cs-pollucite zeolite nanocrystals}

Initially, cesium hydroxide monohydrate (10.500 g, 99.5\%, SigmaAldrich), aluminum hydroxide (1.242 g, extra pure, Acros) and distilled water $\left(8.063 \mathrm{~g}\right.$ ) were stirred at $105^{\circ} \mathrm{C}$ for $18 \mathrm{~h}$ until a clear solution was obtained. A clear silicate solution was prepared by dissolving HS-40 (6.581 g, 40\% $\mathrm{SiO}_{2}$, Sigma-Aldrich) and cesium hydroxide monohydrate (5.550 g) into distilled water (6.400 g). Then, the aluminate solution was slowly mixed into to the silicate solution under magnetic stirring $(450 \mathrm{rpm})$. A clear precursor suspension with a chemical composition of $5.5 \mathrm{SiO}_{2}: 1 \mathrm{Al}_{2} \mathrm{O}_{3}$ : $6 \mathrm{Cs}_{2} \mathrm{O}: 140 \mathrm{H}_{2} \mathrm{O}$ was obtained. The precursor solution was transferred into an autoclave and heated at $180{ }^{\circ} \mathrm{C}$ for $120 \mathrm{~min}$ before the solid product was separated, purified using high-speed centrifugation (10000 rpm, $8 \mathrm{~min}$ ) and freeze-dried. The samples heated at different time intervals $(10,25,30,45$ and $60 \mathrm{~min})$ were also prepared following the same procedure.

\section{Characterization}

The solid products were analyzed by using a PANalytical X'Pert PRO XRD instrument system with CuK $\alpha$ radiation $(\lambda=1.5406 \AA$ ). The degree of crystallinity was computed by comparing the intensity of the three most important peaks at $24.3^{\circ}, 26.1^{\circ}$ and $30.7^{\circ}$ of Cs-pollucite sample ( $120 \mathrm{~min}$ ) as $100 \%$ crystalline. The average sizes of zeolite crystals were estimated by using the Scherrer equation. TEM images of amorphous, semi-crystalline and crystalline solids were recorded using a Philips CM12 transmission electron microscope operating at $200 \mathrm{kV}$. The average crystal sizes of zeolites were also estimated using the Image J software by randomly selecting the 50 particles through TEM images. The functional groups of the solids were identified by Fourier Transform Infrared spectroscopy (FTIR) using a Perkin Elmer's System 2000 spectrometer in the wavenumber range of $400-4000 \mathrm{~cm}-1$ ( $\mathrm{KBr}$ : sample ratio $=50: 1)$. The composition, or $\mathrm{Si} / \mathrm{Al}$ ratio, of the solids was measured by using ICP-OES spectrometry (Vista MPX, Varian Inc.). Prior to analysis, the solid was first dissolved in a $0.5 \mathrm{M} \mathrm{HF}$ solution where boric acid was also added to minimize interferences of fluoride during the analysis. The ${ }^{29} \mathrm{Si}$ MAS NMR spectroscopy measurement was performed using a Bruker Avance II $400 \mathrm{MHz}$ spectrometer system (9.4 Tesla). The sample powder was packed into a $4 \mathrm{~mm} \mathrm{ZrO}_{2}$ rotor and spun at $12 \mathrm{kHz}$. The chemical shifts were referred to TMS. A single pulse excitation was applied with a $\pi / 6$ length of $2.1 \mu \mathrm{s}$, a recycle delay of $80 \mathrm{~s}$, accumulated during 2000 scans. ${ }^{33}$ The ${ }^{27} \mathrm{Al}$ MAS NMR spectra were recorded using different configurations (9.4 Tesla; rotor $2.5 \mathrm{~mm} ; 50000$ scans; $\mathrm{p} / 12 \mathrm{rf}$ pulse length of $0.7 \mathrm{~ms}$; recycle delay of $1 \mathrm{~s}$; spinning rate $25 \mathrm{kHz}$ ). The chemical shifts was referred to external $\left[\mathrm{Al}\left(\mathrm{H}_{2} \mathrm{O}\right)_{6}\right]^{3+}$ in $\mathrm{AlCl}_{3}$ aqueous solution.

\section{Catalytic reaction study in cyanoethylation of amines}

Initially, dried Cs-ABW $\left(0.50 \mathrm{~g}, 100{ }^{\circ} \mathrm{C}, 6 \mathrm{~h}\right)$, acrylonitrile $(19 \mathrm{mmol}$, $99 \%$, Merck) and dipropylamine (76 mmol, 99\%, Merck) were mixed in a quartz tube $(10 \mathrm{~mL})$. The tube was sealed with a silicone cap and subjected to instant heating using a Monowave 50 non- microwave instant heating reactor (Anton Paar) at $180{ }^{\circ} \mathrm{C}$ for specific time periods. The resulting reaction solutions after being isolated from the solid catalyst were injected into a GC-FID (Agilent 7890A) and a GC-MS (Agilent 7000 Series Triple Quad $\mathrm{GC} / \mathrm{MS}$ ) instruments for chromatography identification purpose where toluene was used as an internal standard. For the reactions using $\mathrm{NaOH}$ and $\mathrm{KOH}$ as the catalysts, $1.984 \mathrm{mmol}$ of hydroxide, which is equivalent to $0.50 \mathrm{~g}$ of nanosized Cs-pollucite, was used.

\section{Results and discussion}

\section{Macroscopic study of the formation of nanosized Cs-pollucite}

The kinetics of the formation of Cs-pollucite nanozeolite from a clear precursor solution was initiated by mixing both the silicate and aluminate solutions. The solution was subjected to hydrothermal treatment at $180^{\circ} \mathrm{C}$ for $7 \mathrm{~min}$. It was found that the precursor remained clear and no solid product was recovered. However, it turned to cloudy after 15 min of heating. A soft gel was separated upon centrifugation and an amorphous solid with $15.70 \%$ yield was collected after purification and freeze-drying (Figures 1-3). As seen from the TEM image, the amorphous solid exhibited thin sheet like structure (Figure 4a).

A soft gel was still obtained with heating time extended to $25 \mathrm{~min}$. At this stage, the solid yield significantly dropped to $8.45 \%$. According to XRD analysis, the sample was still amorphous, but the amorphous hump at $2 \theta=18-30^{\circ}$ has shifted to $2 \theta=24-33^{\circ}$ (Figure 2b). The TEM image showed that morphological change of amorphous solid occurred where the amorphous entities (ca. 15 $\mathrm{nm}$ ) with irregular shape was formed (Figure 4b). The solid yield increased gradually to $21.26 \%$ upon heating to $30 \mathrm{~min}$. At this time, several diffraction peaks slowly appeared at $2 \theta=24.3^{\circ}$ [321], $26.1^{\circ}$ [400], $30.7^{\circ}$ [332] and $37.2^{\circ}$ [440] while the amorphous phase was still dominant ( $17.78 \%$ crystallinity) (Figures $1-3)$. Thus, it revealed the formation of $\mathrm{Cs}$-pollucite nuclei in this sample. The XRD investigation was further supported by TEM study where crystalline particles (ca. $21 \mathrm{~nm}$ ) embedded in the amorphous solid were observed (Figure 4c). As seen, the semi-crystalline nuclei had nearly identical crystallite size as the amorphous single particles.

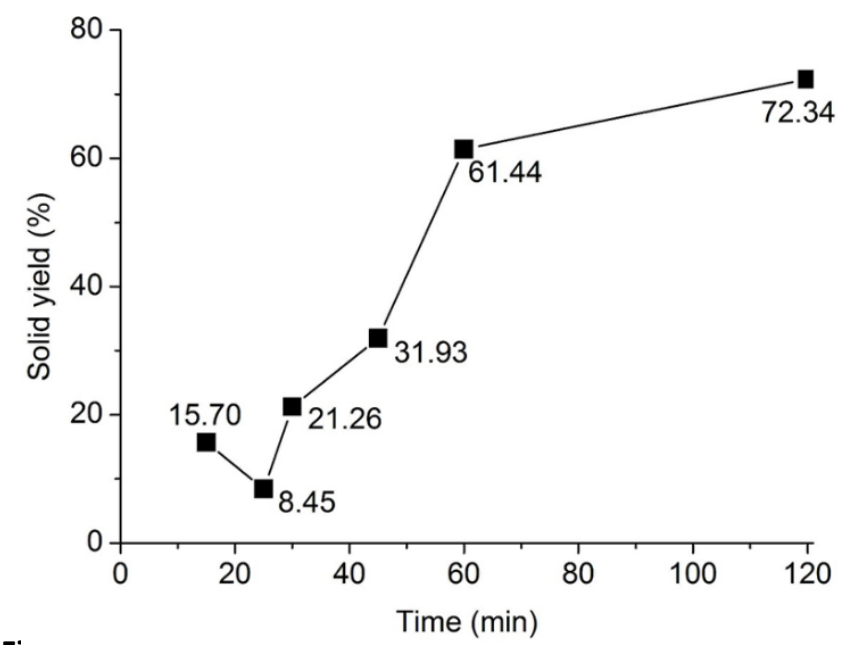

Figure 1. solıa yıeıa atter aıtrerent neatıng tımes or nyarotnermal treatment. 


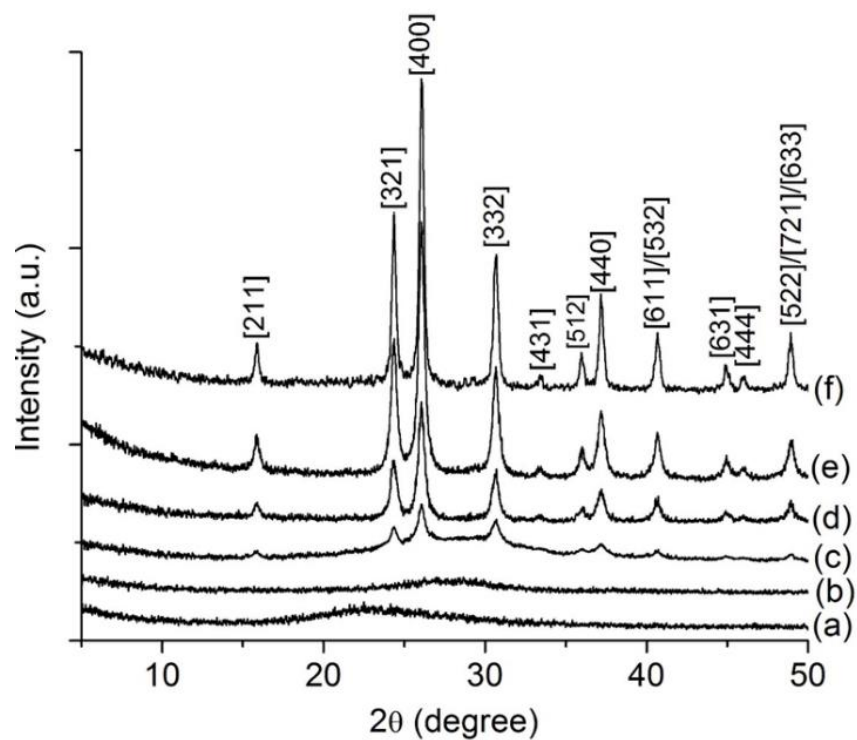

Figure 2. XRD patterns of samples after (a) $15 \mathrm{~min}$, (b) $25 \mathrm{~min}$, (c) $30 \mathrm{~min}$, (d) $45 \mathrm{~min},(\mathrm{e}) 60 \mathrm{~min}$ and (f) $120 \mathrm{~min}$.

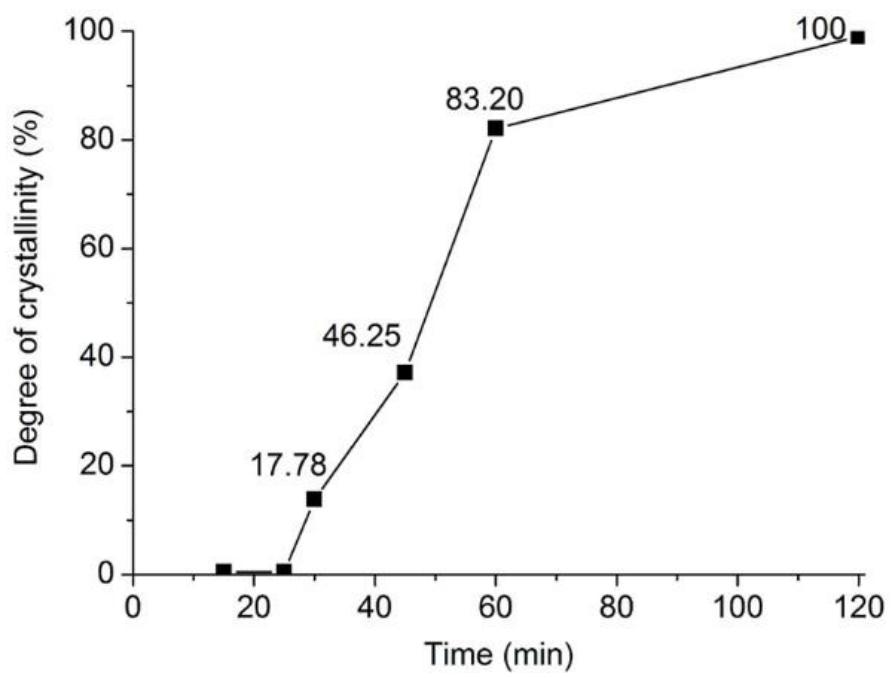

Figure 3. Crystallization rate of solid products after various heating times.

The solid yield kept increasing and reached $31.93 \%$ when the hydrothermal heating time was extended to $45 \mathrm{~min}$ (Figure 1). All the diffraction peaks corresponding to ANA-type structure were clearly shown with the crystallization rate increasing up to $46.25 \%$ (Figure 2d). Further prolonging of the heating time to $60 \mathrm{~min}$ shows an enhancement of crystallization rate reaching $83.20 \%$. At this stage, the intensity of all diffraction peaks became stronger and the amorphous phase was no longer dominant in the sample (83.20\%). The TEM image also showed that the shape of pollucite was becoming more pronounced where the single nanocrystals of pollucite with trapezohedron shape identical to that of theoretical one, were captured (Figure 4d). As can be seen, amorphous thin layer was still covering the surface of nanocrystals and the nanocrystals were about to dissociate from each other to become an independent single crystal particle (ca. $29 \mathrm{~nm}$ ) (Figure 4d,e). After 120 min of heating, discrete and fully crystalline Cs-pollucite nanoparticles were obtained (Figure 1-3). As seen, no amorphous

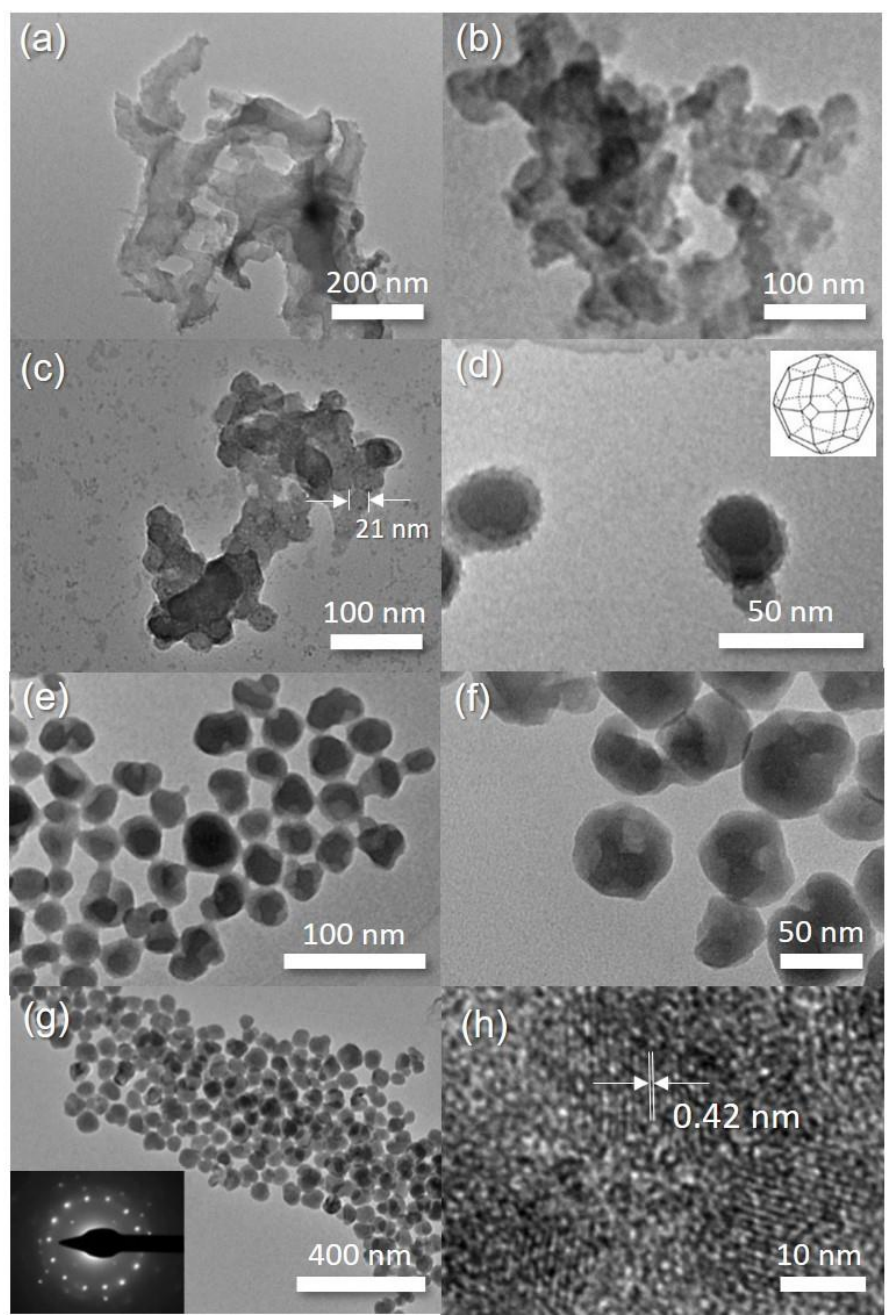

Figure 4. TEM images of samples after (a) $15 \mathrm{~min}$, (b) $25 \mathrm{~min}$, (c) $30 \mathrm{~min},(\mathrm{~d}, \mathrm{e}) 60 \mathrm{~min}$ and (f, g, h) $120 \mathrm{~min}$. Inset of (d) is the theoretical shape of ANA crystalline solid while inset of $(g)$ is the SAED pattern of sample heated for $120 \mathrm{~min}$.

entities were detected. Instead, the nanocrystals grew further and reached ca. $53 \mathrm{~nm}$ (Figure $4 \mathrm{f}, \mathrm{g}$ ). The selected area electron diffraction (SAED) pattern of nanosized Cs-pollucite single crystal viewed along [111] zone axis was also recorded (inset Figure 4g). The SAED pattern showed the nanoparticles to be highly crystalline in nature. The HRTEM image of nanosized Cs-pollucite after $120 \mathrm{~min}$ was also captured (Figure $4 \mathrm{~h}$ ). Clear lattice fringes with a spacing of $0.42 \mathrm{~nm}$ were observed which corresponded to ANA-type zeolite (theoretical pore size is $0.42 \times 0.16 \mathrm{~nm}^{2}$ ). ${ }^{30}$

\section{Microscopic study of the formation of nanosized Cs-pollucite}

The structural evolution of nanosized Cs-pollucite not only can be explained by their macroscopic properties but also by their microscopic properties. The atomic and molecular spectroscopy analyses were hence used to follow the induction, nucleation and crystallization of pollucite nanocrystals. Figure 5 shows the IR spectra of the samples heated at different time intervals. For the sample heated for $15 \mathrm{~min}$, four IR absorption bands were recorded at 1228, 1114, 800 and $474 \mathrm{~cm}^{-1}$ which were attributed to the amorphous aluminosilicate solid (Figure $5 a) .{ }^{7}$ Two signals 
which were assigned to the stretching and bending vibrations of $\mathrm{O}-\mathrm{H}$ groups of water were also detected at 3470 and $1646 \mathrm{~cm}^{-1}$, respectively.

The IR spectrum pattern changed completely when the sample was further heated to $25 \mathrm{~min}$. For instance, the bands at 474 and $800 \mathrm{~cm}^{-1}$, which were assigned to the bending vibration of $\mathrm{TO}_{4}(\mathrm{~T}=\mathrm{Si}$ or $\mathrm{Al})$ and symmetric stretching vibration of Si-O-T, respectively, were disappeared (Figure $5 \mathrm{~b}$ )..$^{34}$ In addition, the IR bands at 1228 and $1114 \mathrm{~cm}^{-1}$ assigning to the internal vibrations of $\mathrm{Si}-\mathrm{O}-\mathrm{T}(\mathrm{T}=\mathrm{Si}, \mathrm{Al})$ asymmetric stretching mode were red shifted to 1133 and $1053 \mathrm{~cm}^{-1}$. A new IR signal corresponded to $\mathrm{Si}-\mathrm{OH}$ bending mode was also detected at $863 \mathrm{~cm}^{-1} .{ }^{35}$ Further heating the precursor to 30 min evidenced the emergence of weak peaks at 769,725 and $620 \mathrm{~cm}^{-1}$ which are characteristic of highly distorted 8-rings subunits present in the pollucite zeolite (Figure 5c). ${ }^{14}$ Furthermore, the IR band due to the bending vibration of $\mathrm{TO}_{4}\left(\mathrm{~T}=\mathrm{Si}\right.$ or Al) re-appeared again at $447 \mathrm{~cm}^{-1}$. The intensity of these four bands kept increasing with heating time indicating phase transformation of sample from amorphous to crystalline solid (Figure $5 \mathrm{c}-\mathrm{e}$ ). Moreover, the bands at around 1130 and 1020 $\mathrm{cm}^{-1}$ were red shifted to lower wavenumbers during crystallization process due to participation and insertion of $\mathrm{Al}$ into the pollucite zeolite framework that resulted in a decrease in the Si/Al ratio.

The change in the chemical composition (e.g. Si/Al ratio) was further supported by ICP-OES spectroscopy. As shown in Table 1, the initial Si/Al was 8.11. With increasing the heating time to 25 $\mathrm{min}$, the Si/Al ratio significantly dropped to 4.74 showing the direct participation of $\mathrm{Al}$ in the crystallization process. The $\mathrm{Si} / \mathrm{Al}$ ratio continued to drop but with slower rate to 3.27 after $30 \mathrm{~min}$ of heating. The Al content in the solid became almost constant after $60 \mathrm{~min}$ and an Si/Al ratio of 2.12 was reached at the end of the crystallization process. On the other hand, the Cs content in the solids showed opposite trend. The initial Cs/Al ratio which was 0.37 increased to 0.76 after $25 \mathrm{~min}$ and the Cs content slowly raised and reached to nearly unity after $60 \mathrm{~min}$.

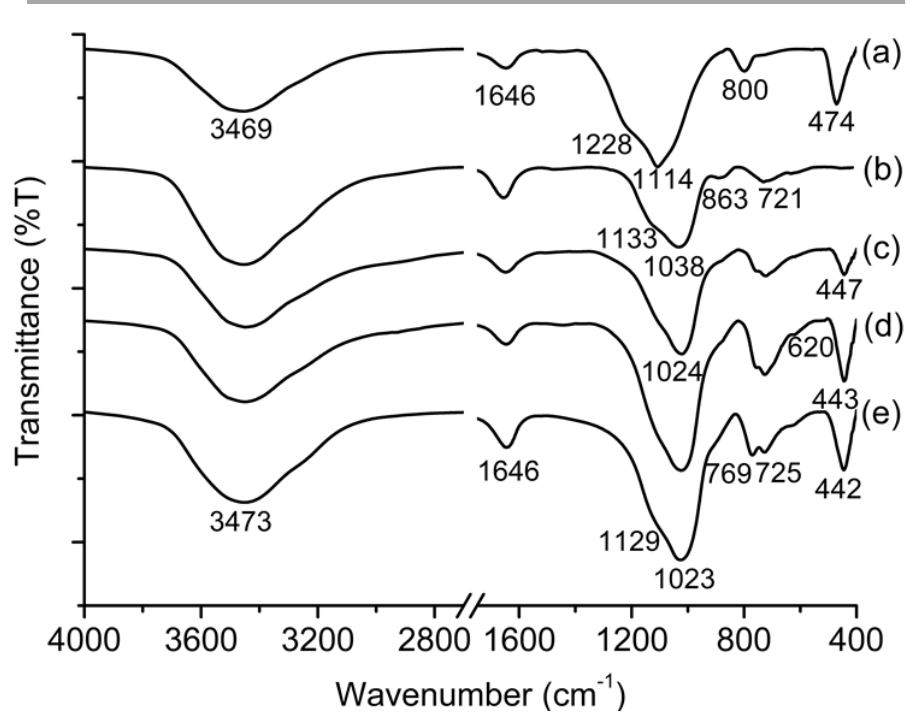

Figure 5. IR spectra of solid products after hydrothermal synthesis for (a) $15 \mathrm{~min}$, (b) $25 \mathrm{~min}$, (c) $30 \mathrm{~min}$, (d) $60 \mathrm{~min}$ and (e) $120 \mathrm{~min}$.
Table 1. Si and Al elemental analysis of the solid products obtained after various heating times.

\begin{tabular}{|c|c|c|c|c|}
\hline & $\mathrm{Si}$ & $\mathrm{Al}$ & Cs & $\mathrm{Cs} / \mathrm{Al} \quad \mathrm{Si} /$ \\
\hline
\end{tabular}

\begin{tabular}{lllllllll}
\hline $15 \min$ & 220.7 & 7.9 & 26.2 & 1.0 & 47.7 & 0.4 & 0.37 & 8.11 \\
$25 \mathrm{~min}$ & 146.6 & 5.2 & 29.9 & 1.1 & 111.4 & 0.8 & 0.76 & 4.74 \\
$30 \mathrm{~min}$ & 121.5 & 4.3 & 35.7 & 1.3 & 151.0 & 1.1 & 0.86 & 3.27 \\
$45 \mathrm{~min}$ & 123.2 & 4.4 & 49.1 & 1.8 & 222.5 & 1.7 & 0.92 & 2.41 \\
$60 \min$ & 121.7 & 4.3 & 53.5 & 2.0 & 269.4 & 2.0 & 1.02 & 2.19 \\
$120 \mathrm{~min}$ & 133.4 & 4.8 & 60.6 & 2.2 & 301.2 & 2.3 & 1.01 & 2.12
\end{tabular}

${ }^{27} \mathrm{Al}$ and ${ }^{29} \mathrm{Si}$ solid state MAS NMR spectroscopy is a very powerful technique to follow the evolution of zeolites and microporous aluminophosphates. ${ }^{36-39}$ Hence, the ${ }^{27} \mathrm{Al}$ solid state MAS NMR spectra of all samples were also recorded. All spectra only indicated a strong peak at 56-59 ppm which was attributed to the Al species in tetrahedral coordination (Figure 6). Hence, the NMR spectroscopy study could prove the direct participation of Al in the formation of pollucite nanocrystals but it did not give much detailed information on the samples with different crystallinity since this tetrahedral Al species is one of the basic building units in both amorphous and zeolite solids. Nevertheless, the $\mathrm{Al}_{\text {Tetrahedral }}$ peak at ca. $-58 \mathrm{ppm}$ became more symmetrical and narrower in the solid sample heated after $30 \mathrm{~min}$, revealing the chemical surrounding of the Al species is becoming more homogeneous when the samples are more crystalline (Figure $6 \mathrm{c}-\mathrm{e}$ ).

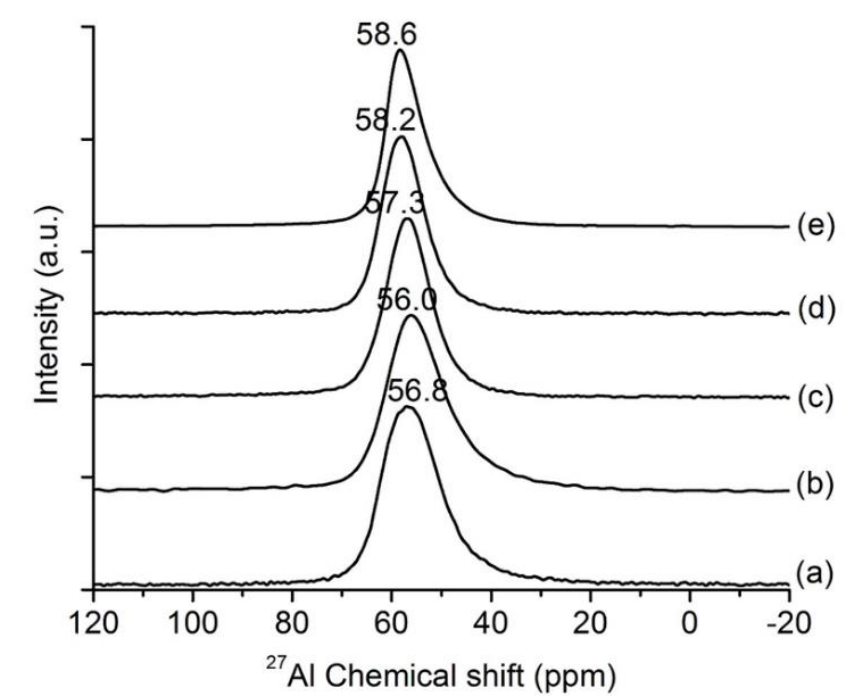

Figure 6. ${ }^{27} \mathrm{Al}$ solid state MAS NMR spectra of samples heated after (a) $15 \mathrm{~min}$, (b) $25 \mathrm{~min}$, (c) $30 \mathrm{~min}$, (d) $60 \mathrm{~min}$ and (d) $120 \mathrm{~min}$.

The ${ }^{29} \mathrm{Si}$ MAS NMR spectra for samples heated at different time intervals were also recorded (Figure 7). As shown, it provided more useful information on the chemical environment around the Si atoms in the amorphous, semi- and fully crystalline solids. A broad and non-symmetrical peak was observed from -70 to -120 

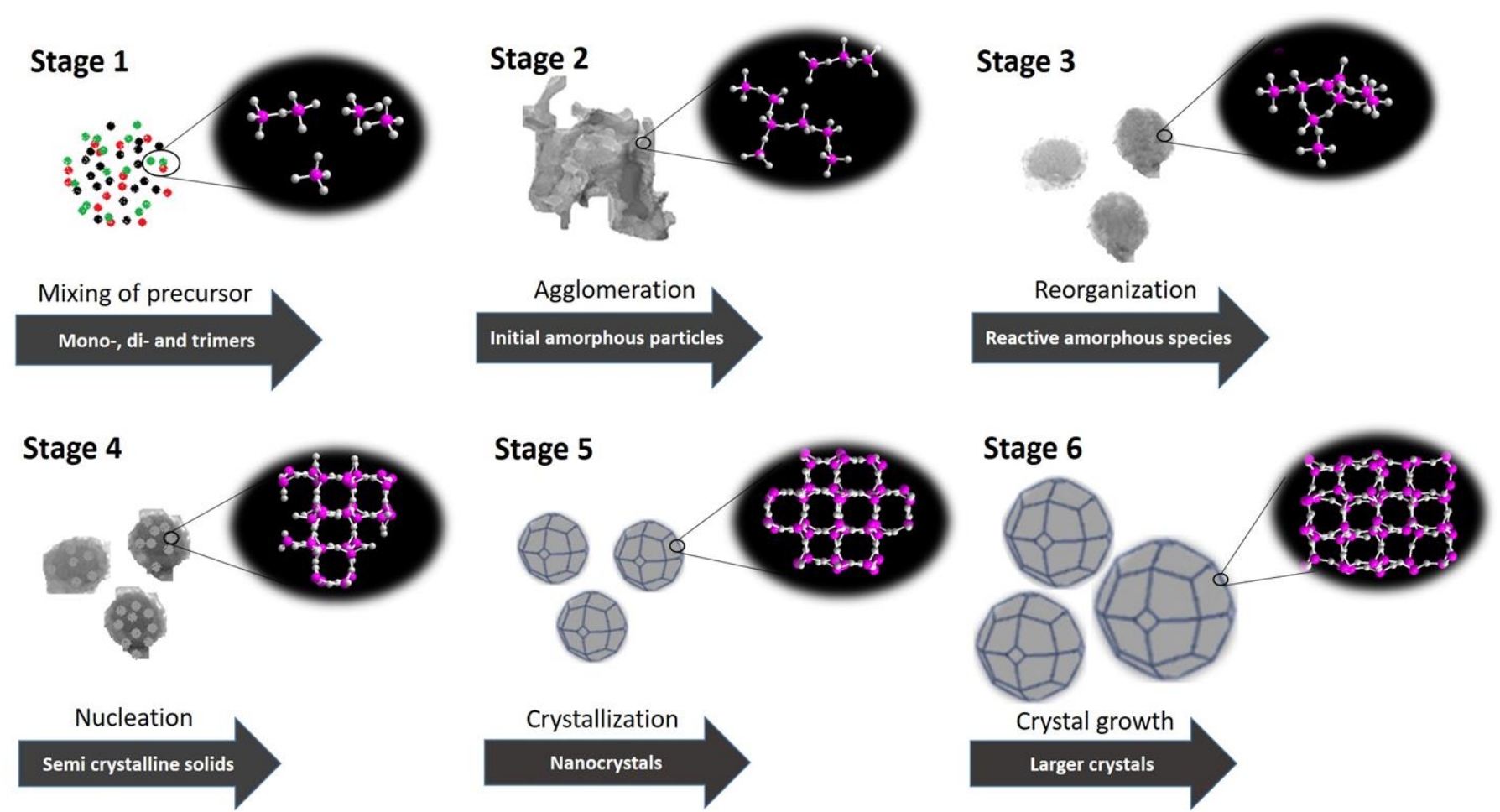

Figure 8. Mechanism of the formation of nanosized Cs-pollucite zeolite. Inset: Framework structure of solid. Pink: Si or Al atom, and white: $\mathrm{O}$ atom. Cs atom is not shown.

ppm which could be deconvoluted into 4 peaks (Figure 7a). The peak at $-111.4 \mathrm{ppm}$ revealed the presence of non-reacted silica species in the form of $\mathrm{Si}(\mathrm{OSi})_{4}$. The peaks at $-102.2 \mathrm{ppm}$ was due to the $\mathrm{Q}_{4}\left(\mathrm{Si}(\mathrm{OSi})_{3}(\mathrm{OAI})\right)$ and/or $\mathrm{Q}_{3}\left(\mathrm{Si}(\mathrm{OSi})_{3}(\mathrm{OH})\right)$ units, while the peak at $-96.8 \mathrm{ppm}$ was attributed to the $\mathrm{Q}_{3}\left(\mathrm{Si}(\mathrm{OSi})_{2}(\mathrm{OAI})_{2}\right)$ and/or $\mathrm{Q}_{3}\left(\mathrm{Si}(\mathrm{OSi})_{2}(\mathrm{OAI})(\mathrm{OH})\right)$ units. $^{36}$ Another peak observed at -85.5 ppm was due to the $\mathrm{Q}_{2}\left(\mathrm{Si}(\mathrm{OSi})(\mathrm{OAl})_{3}\right)$ and/or $\mathrm{Q}_{3}\left(\mathrm{Si}(\mathrm{OAl})_{2}(\mathrm{OSi})(\mathrm{OH})\right)$ units. When the sample was heated to $25 \mathrm{~min}$, the peak at -111.4 ppm disappeared (Figure 7b). Only 2 peaks were observed at -88.7 and -96.6 ppm which were due to $Q_{3}$ and $Q_{4}$ units, respectively. Thus, the NMR investigation was in line with the XRD observation on the phase reorganization of amorphous solid. The symmetry peaks attributing to the unique $\mathrm{Si}$ crystallographic sites $\left(\mathrm{Q}_{1}\right.$ : $\mathrm{Si}(\mathrm{OAl})_{4}$ and $\mathrm{Q}_{2}$ : $\left.\mathrm{Si}(\mathrm{OSi})(\mathrm{OAl})_{3}\right)$ of ANA structure started to appear at ca. -85.5 and $-91.0 \mathrm{ppm}$, respectively after $30 \mathrm{~min}$ while another peak due to amorphous $\mathrm{Q}_{3}$ species, viz. $\left(\mathrm{Si}(\mathrm{OSi})_{2}(\mathrm{OAI})_{2}\right)$ and/or $\left(\mathrm{Si}(\mathrm{OSi})_{2}(\mathrm{OAl})(\mathrm{OH})\right)$ groups, was slightly shifted due to the change of the chemical environment in semi-crystalline solids (Figure $7 \mathrm{c}$ )..$^{40}$ The latter peak slowly disappeared with time and only 2 peaks at -85.2 and -92.1 ppm were observed by the fully crystalline sample (120 min) (Figure 7d, e).

\section{Nucleation process and crystal growth mechanism of nanosized Cs-pollucite}

Cs-pollucite zeolite is normally synthesized under extreme condition $\left(200-300{ }^{\circ} \mathrm{C}, 300-850\right.$ bar) where it is inter-converted from natural zeolite and clay. In order to reduce the zeolite crystal size, supersaturation environment is essential to allow nucleation

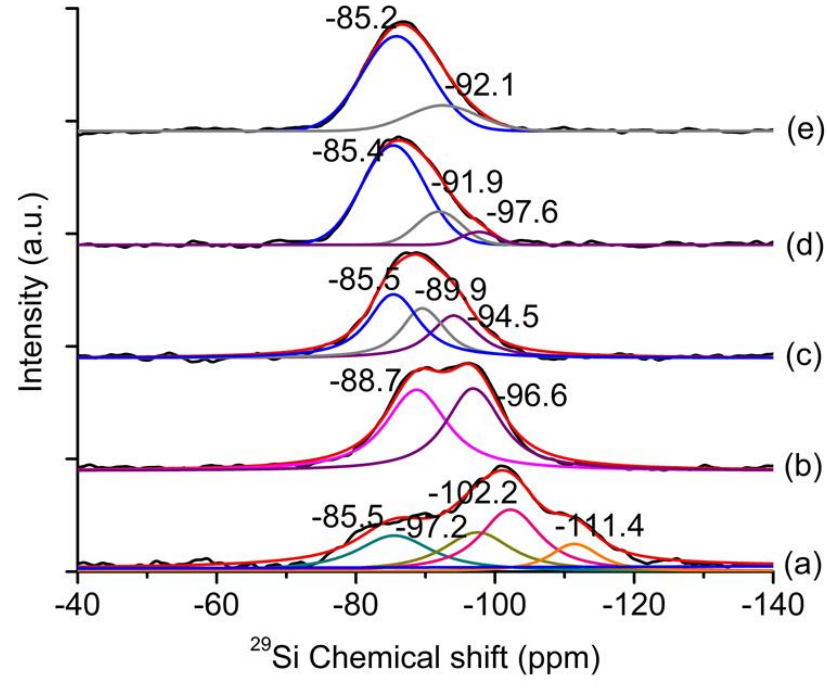

Figure 7. ${ }^{29} \mathrm{Si}$ solid state MAS NMR spectra of samples heated after (a) $15 \mathrm{~min}$, (b) $25 \mathrm{~min}$, (c) $30 \mathrm{~min}$, (d) $60 \mathrm{~min}$ and (e) $120 \mathrm{~min}$.

more favourable than crystal growth. Such condition can be achieved by increasing the $\mathrm{pH}$ of precursor via increasing the concentration of organic template and metal hydroxide, or reducing the water content. ${ }^{41}$ Furthermore, the use of low temperature allows exploration of metastable crystalline phase with open-framework structure and unique properties..$^{42}$ In this work, the crystal growth of nanosized Cs-pollucite zeolite is studied in a very reactive hydrosol free of organic template and using more gentle synthesis condition $\left(180^{\circ} \mathrm{C},<120 \mathrm{~min}\right)$. 
The hydrothermal formation of nanosized Cs-pollucite via organotemplate-free pathway is shown in Figure 8 after visual, spectroscopy and microscopy investigations are considered. Initially, the precursor solution is clear upon mixing of both aluminate and silicate solutions even after stirring for $1 \mathrm{~h}$ at room temperature. The precursor is then heated at higher temperature $\left(180^{\circ} \mathrm{C}\right)$ to enhance the crystallization rate. In the first $7 \mathrm{~min}$ of heating, the precursor solution remains clear and no solid product is formed. In this stage (Stage 1 ), the Si and Al atoms exist in simple monomeric, dimeric and/or trimeric species forms.

Polymerization starts to take place when the precursor is further heated to $15 \mathrm{~min}$. A cloudy colloidal solution is formed but the solid yield is considerably low (15.70\%). The inorganic nutrients are composed of $\mathrm{Si}(\mathrm{OSi})_{4}, \mathrm{Si}(\mathrm{OSi})_{3}(\mathrm{OAl}), \mathrm{Si}(\mathrm{OSi})_{3}(\mathrm{OH})$, $\mathrm{Si}(\mathrm{OSi})_{2}(\mathrm{OAI})_{2}, \quad \mathrm{Si}(\mathrm{OSi})_{2}(\mathrm{OAI})(\mathrm{OH}), \quad \mathrm{Si}(\mathrm{OSi})(\mathrm{OAl})_{3} \quad$ and $\mathrm{Si}(\mathrm{OAI})_{2}(\mathrm{OSi})(\mathrm{OH})$ units which are present, along with free $\mathrm{Cs}^{+}$and tetrahedral Al species as well, in the precursor (Stage 2).

When the precursor is further heated to $25 \mathrm{~min}$, the solid yield reduces to $8.45 \%$ due to the successive dissolution of initial amorphous entity to generate soluble nutrient species for nuclei growth. The XRD, IR and NMR spectroscopy data also show that amorphous phase reorganization into more reactive amorphous intermediate has taken place (Stage 3). The functional groups and the chemical environment of the solid change significantly. Furthermore, the morphology of the solid changes into 3D solid with irregular shape. At this stage, $\mathrm{Al}^{3+}$ and $\mathrm{Cs}^{+}$species are actively participated in the construction of amorphous framework where $\mathrm{Al}^{3+}$ is incorporated in the solid as Al tetrahedral form while $\mathrm{Cs}^{+}$ serves as extraframework cation and mineralizer.

Polymerization further takes place at $30 \mathrm{~min}$ (Stage 4). The $-\mathrm{OH}$ groups bound to $\mathrm{Al}$ and $\mathrm{Si}$ atoms polycondense to form longer polymer chains containing $\left.\mathrm{Si}(\mathrm{OSi})_{2}(\mathrm{OAI})_{2}\right), \mathrm{Si}(\mathrm{OSi})_{2}(\mathrm{OAI})(\mathrm{OH})$, $\mathrm{Si}(\mathrm{OAl})_{4}$ and $\mathrm{Si}(\mathrm{OSi})(\mathrm{OAI})_{3}$ units. As a result, more solids precipitate out (solid yield increases). At this stage, Cs-pollucite nuclei, which has almost similar size as the amorphous single particles, are formed and embedded in the bulk amorphous solid as confirmed by XRD and NMR analyses. The crystallization rate speeds up, and the degree of crystallinity is significantly enhanced after $30 \mathrm{~min}$ onwards. The nutrients from the amorphous material are gradually consumed and phase transformation from amorphous entity to crystalline particles occurs. After $60 \mathrm{~min}$, the ANA crystalline phase is becoming more dominant ( $83.20 \%$ crystallinity) (Stage 5). Cs-pollucite nanocrystals (ca. $29 \mathrm{~nm}$ ) with trapezohedron shape are formed but they are still slightly covered by an amorphous thin layer. The nanocrystals are about to dissociate from each other to become an independent single crystal particle. After $120 \mathrm{~min}$ of heating, the nutrients in the amorphous entity are completely consumed forming discrete and fully crystalline Cs-pollucite nanocrystals (Stage 6). The crystalline framework of $\mathrm{Cs}$-pollucite is made up of $\mathrm{Si}(\mathrm{OAI})_{4}$ and $\mathrm{Si}(\mathrm{OSi})(\mathrm{OAI})_{3}$ units, producing a high-alumina zeolite $(\mathrm{Si} / \mathrm{Al}$ ratio $=2.12)$. The $\mathrm{Cs} / \mathrm{Al}$ ratio reaches nearly unity because every framework $\mathrm{Al}$ species (in tetrahedral form) carrying a negative charge is counterbalanced by a $\mathrm{Cs}^{+}$cation. Furthermore, the nanocrystals also grow further (ca. $55 \mathrm{~nm}$ ) by consuming the nutrients released from the re-dissolution of less stable and smaller crystal domains by the Oswald ripening rule.

\section{Catalytic reaction study in cyanoethylation of amines}

Cyanoethylation of dipropylamine was used as a model reaction to investigate the catalytic properties of nanosized Cs-pollucite. The reaction was performed under non-microwave instant heating condition $\left(180^{\circ} \mathrm{C}\right)$ where this heating mode provides very fast and homogeneous heating similar to microwave heating but with different heating mechanism. ${ }^{43,44}$ The results show that the nanosolid catalyst is very active with $89.6 \%$ conversion after 50 min of heating (Figure 9). The catalytic performance is also compared with two most common homogeneous base catalysts, namely $\mathrm{NaOH}$ and $\mathrm{KOH}$. Interestingly, nanosized Cs-pollucite exhibits stronger catalytic activity than $\mathrm{KOH}(84.8 \%)$ and $\mathrm{NaOH}$ (79.7\%). Thus, it indicates that Cs-pollucite nanocrystals can be used as an eco-friendly and reusable solid base catalyst in organic syntheses.

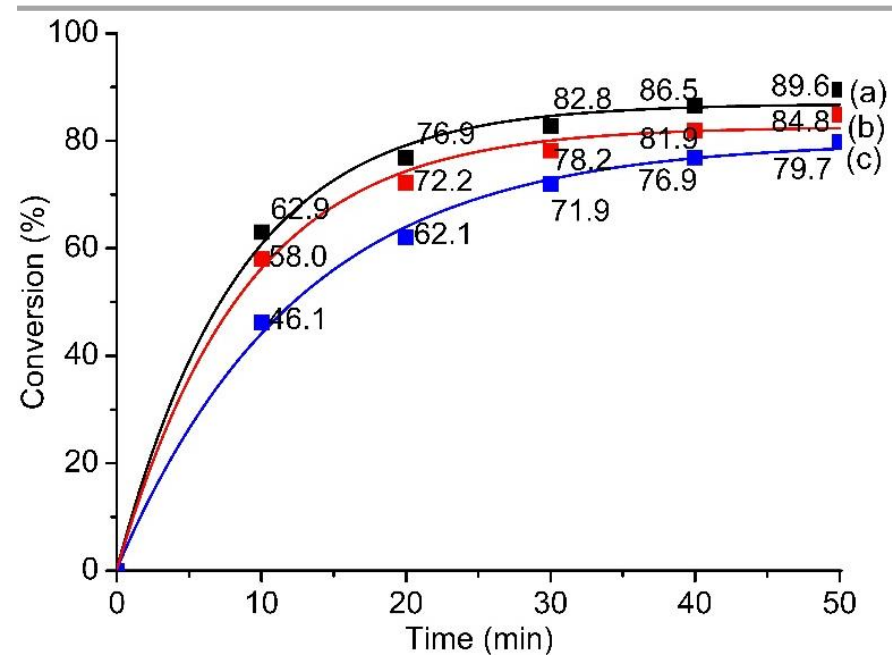

Figure 9. Cyanoethylation of dipropylamine over (a) nanosized Cspollucite, (b) $\mathrm{KOH}$ and (c) $\mathrm{NaOH}$ under non-microwave instant heating at $180^{\circ} \mathrm{C}$.

\section{Conclusion}

A detailed macroscopic and microscopic investigation of crystallization of nanosized Cs-pollucite zeolite in organotemplate-free and clear precursor suspension has been reported. The study shows that Cs-pollucite nanocrystals can be easily obtained within $120 \mathrm{~min}$ when a very reactive precursor sol is used. The formation of Cs-pollucite zeolite involves mixing of $\mathrm{Al}$ and Si simple units, oligomerization of inorganic species to form initial amorphous solid, successive dissolution and polymerization of oligomers to form active amorphous entity (induction), nucleation, crystallization and finally crystal growth. The resulting nanocrystals, which have crystallite size of ca. $55 \mathrm{~nm}$, display trapezohedron morphology. The colloidal stable Cs-pollucite nanocrystals are high-alumina zeolite $(\mathrm{Si} / \mathrm{Al}$ ratio $=2.12)$ and the negative charges induced by the presence of Al atoms in the framework are counter-balanced by $\mathrm{Cs}^{+}$cations. The synthesis reported in this paper is highly appreciated since colloidal stable Cs-pollucite nanozeolite can be crystallized free of organic template and under mild condition $\left(180^{\circ} \mathrm{C},<120 \mathrm{~min},<25\right.$ bar $)$ enables safe and simple scale-up operation. Furthermore, the cyanoethylation of dipropylamine catalytic study concludes that 
Cs-pollucite nanocrystals are a potential solid base catalyst and can be an alternative replacement to $\mathrm{NaOH}$ and $\mathrm{KOH}$ homogeneous base catalysts.

\section{Acknowledgments}

The financial support from FRGS (203/PKIMIA/6711642) grant is gratefully acknowledged. The doctoral scholarship from University of Hail, Saudi Arabia is also acknowledged.

\section{References}

1 S.M. Al-Jubouri, S.M. Holmes, Chem. Eng. J., 2017, 308, 476.

2 G. Majano, E.-P. Ng, L. Lakiss, S. Mintova, Green Chem., 2011, 13, 2435.

3 B. Liu, Z. Chen, J. Huang, H. Chen, Y. Fang, Micropor. Mesopor. Mater., 2019, 273, 235.

4 E.-P. Ng, D.T.-L. Ng, H. Awala, K.-L. Wong, S. Mintova, Mater. Lett., 2014, 132, 126.

5 J. Huve, A. Ryzhikov, H. Nouali, V. Lallia, G. Augé, T.J. Daou, RSC Adv., 2018, 8, 29248.

6 M. Rahimi, E.-P. Ng, K. Bakhtiari, M. Vinciguerra, H.A. Ahmad, H. Awala, S. Mintova, M. Daghighi, F.B. Rostami, M. de Vries, M.M. Motazacker, M.P. Peppelenbosch, M. Mahmoudi, F. Rezaee, Sci. Rep., 2015, 5, 17259.

7 S.-F. Wong, K. Deekomwong, J. Wittayakun, T.C. Ling, O. Muraza, F. Adam, E.-P. Ng, Mater. Chem. Phys. 2017, 196, 295.

8 S. Mintova, J. Grand, V. Valtchev, C.R. Chim., 2016, 19, 183.

9 L. Tosheva, E.-P. Ng, S. Mintova, M. Hölzl, T.H. Metzger, A.M. Chem. Mater., 2008, 20, 5721.

10 T.M.A. Ghrear, S. Rigolet, T.J. Daou, S. Mintova, T.C. Ling, S.H. Tan, E.-P. Ng, Micropor. Mesopor. Mater., 2019, 277, 78.

11 E.-P. Ng, L. Delmotte, S. Mintova, Green Chem., 2008, 10, 1043.

12 E.-P. Ng, S.S. Sekhon, S. Mintova, Chem. Commun., 2009, 0, 1661.

13 G. Majano, K. Raltchev, A. Vicente, S. Mintova, Nanoscale, 2015, 7, 5787.

14 A.G. Mohammad S, N.H. Ahmad, K. Goldyn, S. Mintova, T.C. Ling, E.-P. Ng, Mater. Res. Exp., 2018, 6, 025026.

15 Y. Kamimura, W. Chailittisilp, K. Itabashi, A. Shimojima, T. Okubo, Chem. Asian J., 2010, 5, 2182.

16 X. Chen, D. Xi, Q. Sun, N. Wang, Z. Dai, D. Fan, V. Valtchev, J. Yu, Micropor. Mesopor. Mater., 2016, 234, 401.

17 E.-P. Ng, H. Awala, J.-P. Ghoy, A. Vicente, T.C. Ling, Y.H. Ng, S. Mintova, F. Adam, Mater. Chem. Phys., 2015, 159, 38.

18 H. Awala, J.P. Gilson, R. Retoux, P. Boullay, J.M. Goupil, V. Valtchev, S. Mintova, Nat. Mater., 2015, 14, 447.

19 V.P. Valtchev, K.N. Bozhilov, J. Phys. Chem. B, 2004, 108, 15587.

20 J. Kecht, B. Mihailova, K. Karaghiosoff, S. Mintova, T. Bein, Langmuir, 2004, 20, 5271.

21 S. Mintova, N.H. Olson, V. Valtchev, T. Bein, Science, 1999, 283, 958.

22 E.-P. Ng, G.K. Lim, G.-L. Khoo, K.-H. Tan, B.S. Ooi, F. Adam, T.C. Ling, K.-L. Wong, Mater. Chem. Phys., 2015, 155, 30.

23 M. Tsapatsis, T. Okubo, M. Lovallo, M.E. Davis, Mater. Res. Soc. Symp. Proc., 1995, 371, 21.
24 Y. Liu, M. Sun, C.M. Lew, J. Wang, Y. Yan, Adv. Funct. Mater., 2008, 18, 1732.

25 Y.-W. Cheong, K.-L. Wong, T.C. Ling, E.-P. Ng, Mater. Express, 2018, 8, 1.

26 K. Jiao, X. Xu, Z. Lv, J. Song, M. He, H. Gies, Micropor. Mesopor. Mater., 2016, 225, 98.

27 Y. Ni, A. Sun, X. Wu, G. Hai, J. Hu, T. Li, G. Li, Micropor. Mesopor. Mater., 2011, 143, 435.

28. T. Kurniawan, O. Muraza, K. Miyake, A.S. Hakeem, Y. Hirota, A.M. Al-Amer, N. Nishiyama, Ind. Eng. Chem. Res., 2017, 56, 4258.

29 W. Fan, K. Morozumi, R. Kimura, T. Yokoi, T. Okubo, Langmuir, 2008, 24, 6952.

30 IZA-SC Database of Zeolite Structures. http://www.izastructure.org/ databases/.

31 Y. Yokomori, K. Asazuki, N. Kamiya, Y. Yano, K. Akamatsu, T. Toda, A. Aruga, Y. Kaneo, S. Matsuoka, K. Nishi, S. Matsumoto, Sci. Rep., 2014, 4, 4195.

32 Y. Chen, Z. Jing, K. Cai, J. Li, Chem. Eng. J., 2018, 336, 503.

33 S.-F. Wong, H. Awala, A. Vincente, R. Retoux, T.C. Ling, S. Mintova, R.R. Mukti, E.-P. Ng, Mater. Chem. Phys., 2017, 196, 295.

34 Z. Yan, D. Ma, J. Zhang, X. Liu, X. Han, X. Bao, F. Chang, L. Xu, Z. Liu, J. Mol. Catal. A: Chem., 2003, 194, 153.

35 B.-Z. Zhan, M.A. White, M. Lumsden, J.M. -Neuhaus, K.N. Robertson, T.S. Cameron, M. Gharghouri, Chem. Mater., 2002, 14, 3636.

36 I.I. Ivanova, Y.G. Kolyagin. I.A. Kasyanov, A.V. Yakimov, T.O. Bok. D.N. Zarubin, Angew. Chem. Int., 2017, 56, 15344.

37 A. Aerts, C.E.A Kirschhock, J.A. Martens, Chem. Soc. Rev., 2010, 39, 4626.

38 S.-F. Wong, H. Awala, A. Vincente, R. Retoux, T.C. Ling, S. Mintova, R.R. Mukti, E.-P. Ng, Micropor. Mesopor. Mater., 2017, 249, 105.

39 F. Taulelle, M. Haouas, C. Gerardin, C. Estournes, T. Loiseau, G. Ferey, Colloid Surface A, 1999, 158, 299.

40 G. Engelhardt, Solid state NMR spectroscopy applied to zeolites, Stud. Surf. Sci. Catal. 2001, 137, 387.

41 M. Kamali, S. Vaezifar, H. Kolahduzan, A. Malekpour, M.R. Abdi. Powder Technol., 2009, 189, 52.

42 V.P. Valtchev, K.N. Bozhilov, J. Phys. Chem. B, 2004, 108, 15587. 


\section{Micro- and Macroscopic Observations of the Nucleation and Crystal Growth of Nanosized Cs-Pollucite in Organotemplate-free Hydrosol}

Eng-Poh Ng, $\uparrow$ Aleid Ghadah Mohammad S, Severinne Rigolet, T. Jean Daou, Svetlana Mintova, Tau Chuan Ling

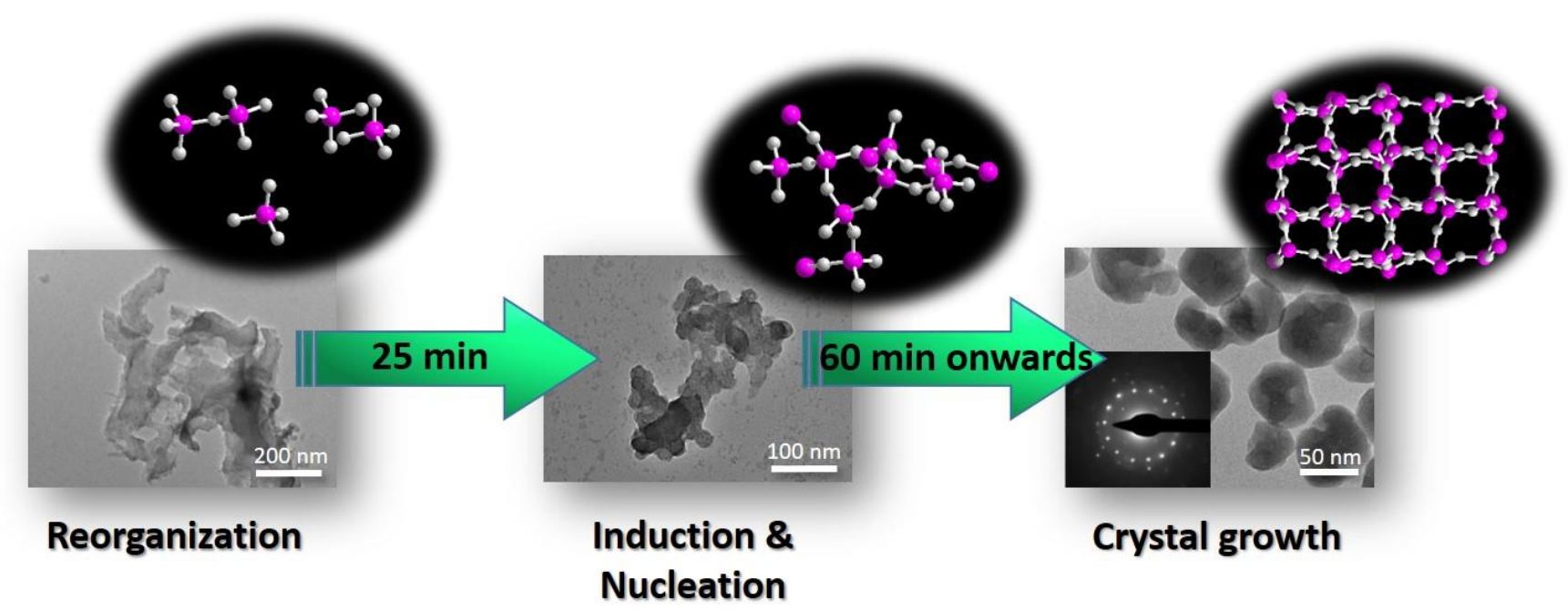

Nucleation and crystal growth of nanosized cesium pollucite zeolite from organotemplate-free hydrosol under mild conditions (low pressure and temperature) are followed and reported. 